\title{
Neurobiological correlates of state-dependent context fear
}

\author{
Mariah A.A. Meyer, ${ }^{1}$ Kevin A. Corcoran, ${ }^{1}$ Helen J. Chen, ${ }^{1}$ Sonia Gallego, ${ }^{1}$ Guanguan Li, ${ }^{2}$ \\ Veda V. Tiruveedhula, ${ }^{2}$ James M. Cook, ${ }^{2}$ and Jelena Radulovic ${ }^{1}$ \\ ${ }^{1}$ Department of Psychiatry and Behavioral Sciences, Northwestern University, Chicago, Illinois 60611, USA; ${ }^{2}$ Department \\ of Chemistry and Biochemistry, University of Wisconsin-Milwaukee, Milwaukee, Wisconsin 53211, USA
}

\begin{abstract}
Retrieval of fear memories can be state-dependent, meaning that they are best retrieved if the brain states at encoding and retrieval are similar. Such states can be induced by activating extrasynaptic $\gamma$-aminobutyric acid type $\mathrm{A}$ receptors $\left(G A B A_{A} R\right)$ with the broad $\alpha$-subunit activator gaboxadol. However, the circuit mechanisms and specific subunits underlying gaboxadol's effects are not well understood. Here we show that gaboxadol induces profound changes of local and network oscillatory activity, indicative of discoordinated hippocampal-cortical activity, that were accompanied by robust and long-lasting state-dependent conditioned fear. Episodic memories typically are hippocampus-dependent for a limited period after learning, but become cortex-dependent with the passage of time. In contrast, state-dependent memories continued to rely on hippocampal GABAergic mechanisms for memory retrieval. Pharmacological approaches with $\alpha-$ subunit-specific agonists targeting the hippocampus implicated the prototypic extrasynaptic subunits $\left(\alpha_{4}\right)$ as the mediator of state-dependent conditioned fear. Together, our findings suggest that continued dependence on hippocampal rather than cortical mechanisms could be an important feature of state-dependent memories that contributes to their conditional retrieval.
\end{abstract}

Important events are typically encoded into memories that are readily accessible for retrieval. However, some memories are formed so that they are inaccessible to retrieval unless the brain is in a similar affective, stress- or drug-induced state as during encoding (Janet 1889; Braun 1984; Spiegel et al. 2011). These memories, known as state-dependent memories, have been studied extensively using various psychoactive drugs (Barnhart and Abbott 1967; Bustamante et al. 1970; Bruins Slot and Colpaert 1999; Romieu et al. 2006; Sanday et al. 2013), with the majority of examples coming from activators of GABAR (Overton 1964; Patel et al. 1979). These receptors also mediate state-dependent learning induced by non-GABAergic drugs, such as morphine (Zarrindast et al. 2006), that act through inhibitory neurons. GABAR type B agonists, such as baclofen, are ineffective (Nakagawa et al. 1993), supporting the view that state-dependent learning is primarily a $\mathrm{GABA}_{\mathrm{A}} \mathrm{R}$-mediated phenomenon. In line with these findings, the $\mathrm{GABA}_{\mathrm{A}} \mathrm{R}$ agonist gaboxadol (GBX), which specifically activates extrasynaptic $\mathrm{GABA}_{\mathrm{A}} \mathrm{R}$ (Chandra et al. 2006), is capable of eliciting state-dependent contextual fear conditioning (Jovasevic et al. 2015).

Initially, memory retrieval processes are thought to depend on hippocampal-cortical interactions, but with the passage of time, the retrieval process becomes increasingly independent of the hippocampus and predominantly regulated by the cortex (Squire and Alvarez 1995). Interestingly, GBX potently activates hippocampal neurons while inhibiting cortical neurons, as indicated by up-regulation of immediate-early gene activity (Jovasevic et al. 2015). This finding suggests that one of the features of GBX-induced brain states supporting state-dependent fear conditioning is a change in the coordination of hippocampal-cortical activity. This is not surprising in view of GBX effects on local

\section{Corresponding author: j-radulovic@northwestern.edu}

Article is online at http://www.learnmem.org/cgi/doi/10.1101//m.045542.117. and circuit network activity in various brain regions (Jessen et al. 2014), however, the specific effects within hippocampal-cortical networks are not well defined.

$\mathrm{GABA}_{\mathrm{A}} \mathrm{R}$ are heterooligomeric pentamers composed of subunits $\alpha_{1-6}, \beta_{1-4}, \gamma_{1-3}, \delta, \varepsilon, \theta, \pi$, and $p_{1-3}$ arranged around a central chloride-conducting pore (Whiting 2003; Olsen and Sieghart $2008,2009)$; though most are composed of two $\alpha$, two $\beta$, and one $\gamma, \delta$, or $\varepsilon$ subunit (Sieghart and Sperk 2002). Although the presence of the $\delta$ subunit correlates with extrasynaptic localization of $\mathrm{GABA}_{\mathrm{A}} \mathrm{R}$ (Belelli et al. 2009) and confers the sensitivity of $\mathrm{GABA}_{\mathrm{A}} \mathrm{R}$ to GBX (Meera et al. 2011), GBX binds nonspecifically to all $\alpha$ subunits of $\mathrm{GABA}_{\mathrm{A}} \mathrm{R}$ (Ebert et al. 1997). Though $\alpha_{4,6}$ subunits seem to preferentially respond to GBX (Brown et al. 2002; Meera et al. 2011), the contribution of individual $\alpha / \delta$-subunit complexes to state-dependent fear conditioning is not known.

Here we investigated the mechanisms by which GBX induces state-dependent learning and memory. As reflected in changes of local field potentials (LFPs) and behavioral pharmacological effects we studied GBX effects on hippocampal-cortical interactions. We also used $\mathrm{GABA}_{\mathrm{A}} \mathrm{R}$ subunit-specific agonists to study the ability of individual $\alpha$ subunits to mediate state-dependent learning.

\section{Results}

Induction of state-dependent learning by GBX

To induce state-dependent contextual fear, mice were injected intrahippocampally (i.h.) with vehicle (Veh) or GBX before contextual fear conditioning (Veh- and GBX-conditioned groups,

(C) 2017 Meyer et al. This article is distributed exclusively by Cold Spring Harbor Laboratory Press for the first 12 months after the full-issue publication date (see http://learnmem.cshlp.org/site/misc/terms.xhtml). After 12 months, it is available under a Creative Commons License (Attribution-NonCommercial 4.0 International), as described at http://creativecommons.org/licenses/by-nc/4.0/. 
respectively) (Jovasevic et al. 2015). Mice were tested for memory retrieval on Veh and GBX on subsequent days (Fig. 1A), and freezing behavior was recorded as an index of learned fear (Blanchard and Blanchard 1969). GBX-conditioned mice showed impaired memory retrieval when tested on Veh, but intact retrieval when tested on GBX, as indicated by robust freezing responses $(n=11-$ 12 mice per group; main effect of test $\operatorname{drug} F_{(1,21)}=9.916, P=$ 0.0048 and interaction effect of conditioning drug $\times$ test drug $F_{(1,21)}=60.68, P<0.0001$ Fig. 1B). In contrast, Veh-injected mice showed intact memory retrieval when tested on Veh and impaired retrieval when tested on GBX. Overall the findings showed that GBX-conditioned mice exhibit state-dependent contextual fear memory.

\section{Effects of GBX on hippocampal-cortical LFPs}

We next measured LFPs in the dorsal hippocampus (DH), retrosplenial cortex (RSC), and anterior cingulate cortex (ACC) to test how GBX affects activity in a hippocampal-cortical network that is necessary for contextual memory retrieval (Frankland et al. 2006; Corcoran et al. 2016). On each test day, there were three recording sessions: in the home cage prior to and $30 \mathrm{~min}$ after an intraperitoneal (i.p.) injection, and during post-injection testing for fear to the conditioning context. On the first test day, mice were injected with Veh; on the second day they were injected with GBX. Similar to i.h. infusions of GBX, i.p. injections caused a reduction in freezing to the conditioning context $\left(t_{(6)}=4.29 ; P=0.005\right.$; data not shown). Recordings were analyzed for power in $\mathrm{DH}$ and peak coherence between DH-RSC and DH-ACC in the $\delta, \theta$, and $\gamma$ frequency bands.

Injection of Veh caused no changes to $\delta, \theta$, or $\gamma$ power in $\mathrm{DH}$, or to DH-RSC or DH-ACC $\theta$ peak coherence (Fig. 2A,C,D). GBX increased DH $\delta$ power $\left(F_{(6,12)}=8.52 ; P=0.005\right)$, whereas $\gamma$ power $\left(F_{(6,12)}=9.58 ; P=0.0033\right.$ Fig. $\left.2 \mathrm{~B}, \mathrm{C}\right)$ and RSC-DH $\theta$ peak coherence $\left(F_{(6,12)}=5.99 ; P=0.016\right)$ decreased.

In the conditioning chamber on the Veh test day, $\mathrm{DH} \delta$ power decreased $\left(F_{(6,12)}=5.59 ; P=0.019\right)$ and $\theta$ power increased $\left(F_{(6,12)}=\right.$ 5.41; $P=0.021)$ compared with the post-injection home cage recording (Fig. 2C). $\theta$ Peak coherence also increased in the DH-RSC $\left(F_{(6,12)}=29.19 ; P<0.001\right)$ and DH-ACC $\left(F_{(6,12)}=21.29 ; P\right.$ $<0.001$ ) site-pairs (Fig. 2D). In the conditioning chamber during the GBX retrieval test, $\delta$ power remained elevated above the preinjection baseline, and there were no changes in $\theta$ or $\gamma$ power relative to the post-injection recording in the home cage. Retrieval test-related increases in DH-RSC and DH-ACC $\theta$ peak coherence
A

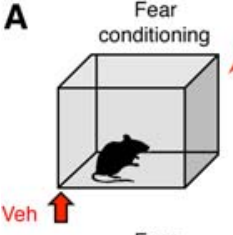

Fear
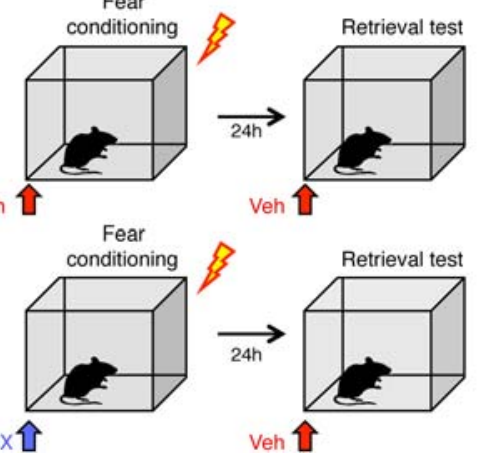
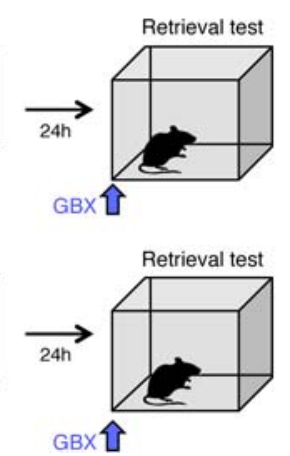

B

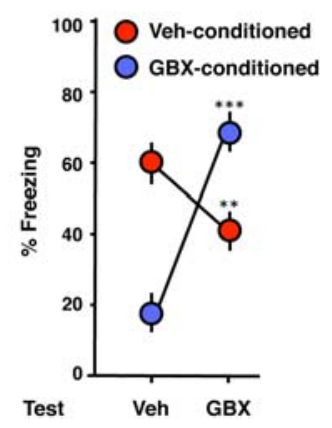

Figure 1. Intrahippocampal GBX induces state-dependent contextual fear. $(A)$ Schematic of the experimental paradigm. Mice were injected i.h. with Veh or GBX before contextual fear conditioning. On alternating days, mice were tested for memory retrieval on Veh or GBX by reexposure to the conditioning context without shock. $(B)$ During the memory tests, GBX-conditioned mice froze significantly more in the presence of GBX than in the presence of Veh. In contrast, Veh-conditioned mice froze significantly more at Veh test than GBX test. $\left({ }^{* *}\right) P<0.01,\left({ }^{* * *}\right) P<0.001$ versus previous test. Error bars represent standard error of the mean. were also blocked by GBX (Fig. 2D), suggesting discoordinated hippocampal-cortical activity during the memory test.

\section{GBX-induced retrieval of recent and remote state-dependent context fear}

Over time, retrieval of episodic-like memories such as contextual fear conditioning shifts from being hippocampus-dependent to hippocampus-independent (Squire and Kandel 2000; Dudai 2004), and comes to rely instead on cortical mechanisms (Lashley 1950; McClelland et al. 1995; Squire and Alvarez 1995). This hippocampal-cortical dialogue, thought to be important for lasting memory storage, begins at the time of encoding (Goshen et al. 2011; Lesburguères et al. 2011). Because GBX disrupted hippocampal-cortical coherence, we next tested whether the ability to retrieve GBX-induced state-dependent contextual fear would eventually become hippocampus-independent. Mice were fear conditioned after i.h. administration of Veh or GBX, and tested on both Veh and GBX 24 and $48 \mathrm{~h}$ post-conditioning, as in the previous experiment. In addition, mice were tested for remote memory retrieval on Veh and GBX 28 and 29 d post-conditioning, respectively. GBX-conditioned male mice froze only when tested on GBX, during both recent and remote tests $(n=9-11$ mice per group; main effect of test drug $F_{(3,54)}=11.6, P<0.001$ Fig. $3 \mathrm{~A}$ ). Significant remote retrieval of state-dependent contextual fear was also observed in females ( $n=8-10$ mice per group; main effect of test drug $F_{(3,51)}=8.3, P<0.001$ Fig. $3 B$ ). In both sexes, the freezing behavior of Veh-conditioned animals was lower on GBX, however, post hoc analysis did not reveal significant differences when compared with the previous Veh test. Thus, retrieval of statedependent contextual fear memory remained dependent on hippocampal mechanisms even at remote time points.

\section{Role of $G A B A_{A} R \alpha$ subunits in state-dependent contextual fear conditioning}

To test whether GBX-induced state-dependent learning depends on the activity of specific $\mathrm{GABA}_{\mathrm{A}} \mathrm{R} \alpha$ subunits, we compared the abilities of $\alpha_{1-6}$ preferential agonists to induce state-dependent contextual freezing. Mice were injected i.h. with Veh, the $\alpha_{1-6}$ agonist GBX, the $\alpha_{1-3}$ preferential agonist zolpidem (Pritchett and Seeburg 1990; Langer et al. 1992; Crestani et al. 2000), or the $\alpha_{5}$ preferential agonists SH-053-R-CH3-2'F (Savić et al. 2008) or MP-III-022 (Stamenić et al. 2016) before contextual fear conditioning. Memory retrieval was assessed over three subsequent days, alternating between off- and on-conditioning drug tests. Only mice that were conditioned on GBX differed in their freezing between tests $(n=7$ mice per group; main effect of conditioning drug $F_{(1,12)}=11.7, P=$ 0.0051 and main effect of test $F_{(2,24)}=$ 4.2, $P=0.0278$ Fig. $4 \mathrm{~A})$; all other groups froze similarly across test days (zolpidem, SH-053-R-CH3-2'F; $n=8-9$ mice per group; no main effects; all $F<2.7$, all $P>$ 0.081 Fig. 4B,C; MP-III-022; $n=7-8$ mice per group; main effect of conditioning drug $F_{(1,12)}=9.491, P=0.0095$ Fig. 4D). Thus, state-dependent contextual fear memory is not encoded ubiquitously by $\mathrm{GABA}_{\mathrm{A}} \mathrm{R} \alpha$-subunit activation.

$\mathrm{GABA}_{\mathrm{A}} \mathrm{R}$ agonists can sometimes substitute for one another in recovering state-dependent memories (Nakagawa and Iwasaki 1995). We therefore tested 
A
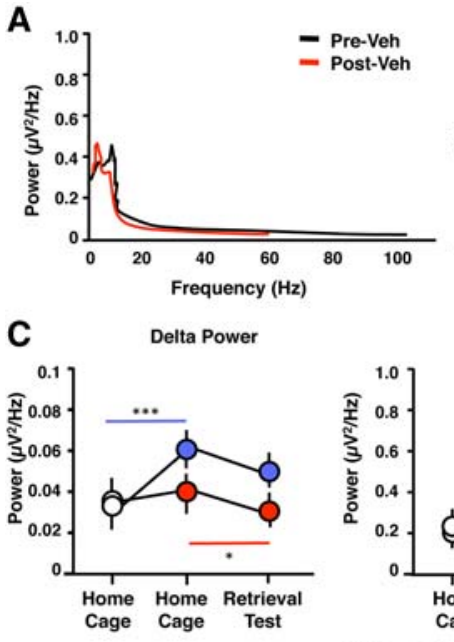
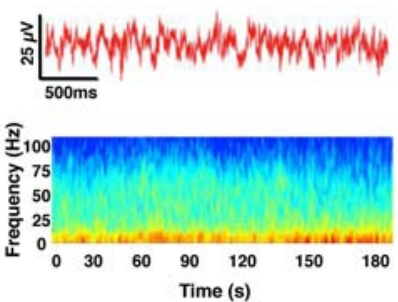

B

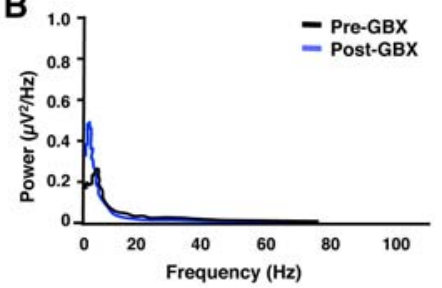

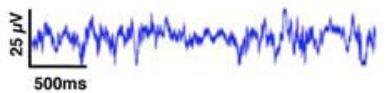

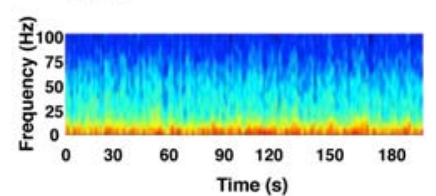

D
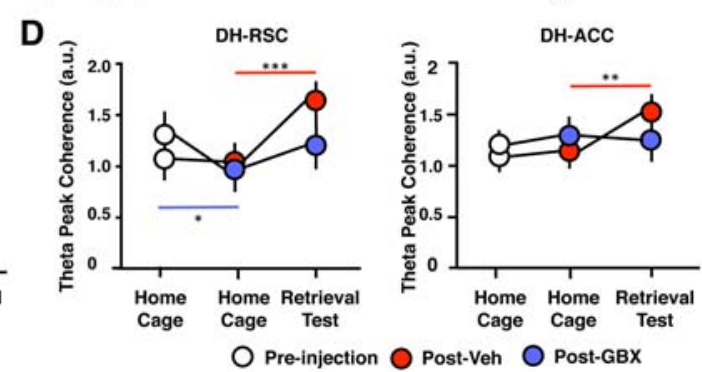

Figure 2. GBX alters hippocampal-cortical network activity. (A) (Left) Power spectral densities obtained Pre- and Post-Veh injection. (Right) Raw LFP and LFP spectrum recorded Post-Veh injection. (B) Same as $A$ for GBX. (C) Hippocampal $\delta$ (left), $\theta$ (center), and $\gamma$ (right) power recorded Pre- (open circles) and Post-Injection (closed circles) in the home cage and during retrieval test. (D) Same as C for DH-RSC (left) and DH-ACC (right) $\theta$ peak coherence. $N=7$ mice per group. $\left.\left(^{*}\right) P<0.05,{ }_{\left({ }^{*}\right)} P<0.01,{ }^{* * *}\right) P<0.001$ versus previous test.

whether the agonists described above can substitute for GBX in recovering retrieval of state-dependent context memories. Mice were injected i.h. with Veh or GBX before contextual fear conditioning and then tested for memory retrieval on consecutive days after i.h. Veh, GBX, zolpidem, SH-053-R-CH3-2'F, and MP-III-022 (Fig 5; $n=9-10$ mice per group; main effect of conditioning drug $F_{(1,16)}=5.5 P=0.0328$ and main effect of test drug $\left.F_{(4,64)}=3.16, P=0.0196\right)$. The freezing behavior of Veh-conditioned animals was significantly reduced by GBX (compared with freezing during the Veh test), and conversely, the freezing behavior of GBX-conditioned mice was significantly elevated on GBX when compared with Veh. Freezing during retrieval testing on zolpidem, SH-053-R-CH3-2'F, and MP-III-022 was indistinguishable from freezing during the Veh test, demonstrating that other $\mathrm{GABA}_{\mathrm{A}} \mathrm{R}$ agonists could not substitute for GBX to induce retrieval of state-dependent contextual fear, such that retrieval is also $\mathrm{GABA}_{\mathrm{A}} \mathrm{R} \alpha$-subunit activation-specific.

\section{Discussion}

Activation of hippocampal extrasynaptic $\mathrm{GABA}_{\mathrm{A}} \mathrm{R}$ via $\mathrm{GBX}$ can cause state-dependent learning. Here we show that GBX may cause this effect by increasing $\delta$ and reducing $\gamma$ oscillations in the hippocampus and disrupting retrieval-induced hippocampal-cortical $\theta$ coherence. Along with these changes, state-dependent fear conditioning induced by GBX remained dependent upon the hippocampus even during remote memory retrieval. The effects of GBX could not be replicated by $\alpha_{1-3}$ or $\alpha_{5} \mathrm{GABA}_{\mathrm{A}} \mathrm{R}$ subunit agonists, suggesting that GBX acted via prototypic extrasynaptic $\alpha_{4}$ or $\alpha_{6}$ receptor subunits.

We observed asymmetry of state-dependent learning on GBX referring to the much greater effect of GBX to recover freezing in GBX-conditioned mice than to impair freezing in Veh-conditioned mice. This finding is consistent with previously observed asymmetry in state-dependent memory (Duncan and Copeland 1975). This asymmetry could be due to the fact that the retrievalrelated processes, such as reconsolidation or extinction, during the Veh test that could render the Veh-conditioned group less sensitive to GBX actions.
Retrieval of memory for contextual fear conditioning is associated with decreased $\delta$ and increased $\theta$ power, along with increased $\theta$ peak coherence between DH and both RSC and ACC (Corcoran et al. 2016). We found that pretest injection of GBX blocked all of these retrieval-related changes. Consistent with previous findings (Vyazovskiy et al. 2005), GBX also increased $\delta$ power, which is inversely correlated with arousal and wakefulness (Bódizs et al. 2001; Dang-Vu et al. 2008), and is typically considered important for offline consolidation of memory during sleep (Binder et al. 2014; Westerberg et al. 2015), rather than for online memory retrieval. Thus, the changes in power and coherence seen after GBX administration may be a neural representation of a state shift supporting the processing of memories with limited access.

It has been shown that the hippocampus has a time-limited role in retrieval of contextual fear memory (Kim and Fanselow 1992; Frankland et al. 2006). This time-dependence serves as a fundamental characteristic of systems consolidation theories, in which the circuits that support memory recall shift (Squire and Kandel 2000; Dudai 2004). One of the central tenets of the systems consolidation hypothesis is that the hippocampus functions as a temporary storage site for information, whereas permanent storage depends on a broadly distributed cortical network (Lashley 1950; McClelland et al. 1995; Squire and Alvarez 1995). Even with the hippocampal independence of remote memories being less certain than it once was (Goshen et al. 2011; Wiltgen and Tanaka 2013), because GBX caused discoordination of LFP coherence across a hippocampal-cortical network, we tested whether GBX-induced statedependent contextual fear would shift cortically over time as predicted by systems consolidation theories. In activating hippocampal extrasynaptic $\mathrm{GABA}_{\mathrm{A}} \mathrm{R}$ at varying times, we observed that GBX-conditioned animals retrieved contextual fear memories, whether tested $48 \mathrm{~h}$ or $29 \mathrm{~d}$ post-conditioning.

Thus, activation of the subset of hippocampal GBX-responsive $\mathrm{GABA}_{\mathrm{A}} \mathrm{R}$ was sufficient to retrieve state-dependent contextual fear memory. Our findings suggest that contextual fear memories encoded in a state-dependent manner remain trapped within the region that encodes them, the hippocampus, and do not become cortically dependent with the passage of time. This finding is in line with previous work showing that state-dependent memories are subcortical in nature and that suppression of cortical activity 

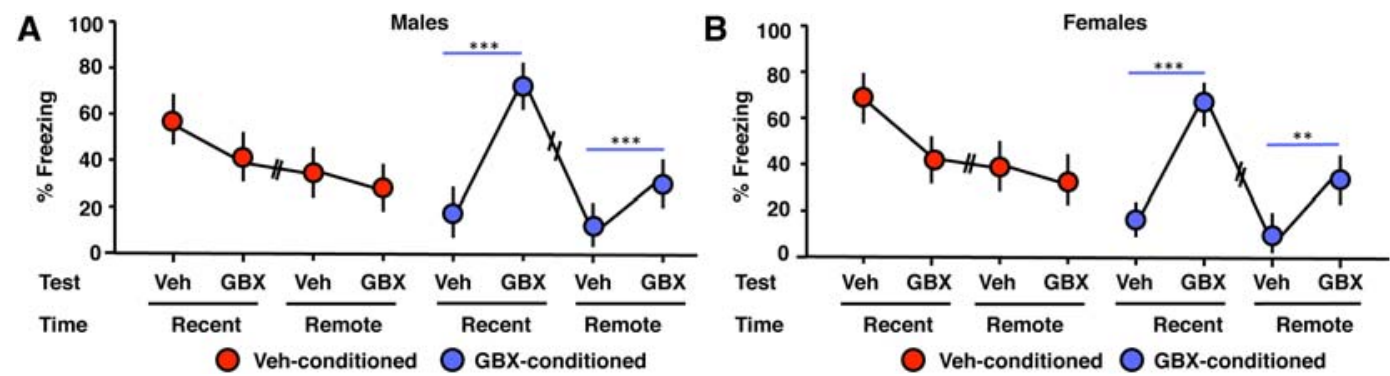

Figure 3. Intrahippocampal GBX promotes recent and remote retrieval of state-dependent contextual fear memory. Freezing of Veh-conditioned mice was similar between Veh and GBX tests. GBX-conditioned mice froze significantly more when tested on GBX, both at recent and remote memory tests. Similar findings were obtained with male $(A)$ and female $(B)$ mice. $\left.\left.{ }^{* *}\right) P<0.01,{ }^{* * *}\right) P<0.001$ versus Veh test, within respective recent or remote time frame. Error bars represent standard error of the mean.

does not impair retrieval of state-dependent memory (Girden and Culler 1937; Jovasevic et al. 2015).

Most rodent studies on fear conditioning and state-dependent memory use male subjects (Overton 1991; Lebron-Milad et al. 2012). It has recently been suggested, however, that freezing behavior, the passive response traditionally used to quantify Pavlovian fear conditioning, may differ between sexes (Gruene et al. 2015). We tested the ability of GBX to elicit state-dependent contextual fear in male and female mice. Both sexes displayed significantly higher freezing when tested on the drug that was present at conditioning, an effect that was found at both recent and remote time points. Thus, at least in this paradigm, state-dependent fear conditioning is sex-independent.

Some of the earliest evidence for state-dependent learning comes from studies with compounds that are known GABAR agonists or positive allosteric modulators, including alcohol (Goodwin et al. 1969; Hinrichsen et al. 1974; Weingartner et al. 1976), amobarbital (Ley et al. 1972), and diazepam (Jensen et al. 1989), all of which bind to multiple $G_{A B A} R$ subunits. Various $G_{A B A} R$ agonists have been tested for the ability to support state-dependent conditioned fear memory, however they have proven ineffective (Davis 1979). This could be due to differential drug effects on synaptic versus extrasynaptic $\mathrm{GABA}_{\mathrm{A}} \mathrm{R}$ as well as preferential actions on $\mathrm{GABA}_{\mathrm{A}} \mathrm{R}$ subunits that might not have the same ability to induce state-dependent fear learning. We delineated which $\alpha$ subunit mediates state-dependent learning in the present paradigm by using $\mathrm{GABA}_{\mathrm{A}} \mathrm{R}$ agonists with a more constrained locus of action. Neither zolpidem (preferential $\alpha_{1-3}$ agonist) nor SH-053-R-CH3-2'F or MP-III-022 (preferential $\alpha_{5}$ agonists) could elicit state-dependent learning of contextual fear, suggesting that GBX induces state-dependent memory through actions on $\alpha_{4,6}$ subunits. This is in agreement with previous findings demonstrating preferential activation of $\mathrm{GABA}_{\mathrm{A}} \mathrm{R} \alpha_{4,6}$ subunits in response to GBX (Brown et al. 2002; Meera et al. 2011), despite the fact that the drugs bind to other $\alpha$ subunits as well. The inability of $\alpha 1$ and $\alpha 5$ agonists to induce state-dependent memory may be due, at least in part, to their actions at both synaptic and extrasynaptic $\mathrm{GABA}_{\mathrm{A}} \mathrm{R}$ (Nusser et al. 1995; Rudolph et al. 1999; Sun et al. 2004; Milenkovic et al. 2013). Moreover, the level of the $\alpha_{6}$ subunit is low in the hippocampus (Lee and Maguire 2014), suggesting that GBX effects are likely mediated by $\alpha_{4}$.

State-dependent memory has been implicated in the development of dissociative symptoms of psychiatric illnesses associated with psychological trauma, such as dissociative amnesia (Janet 1889; Braun 1984; Spiegel et al. 2011). Despite the fact that such memories cannot be recalled, they profoundly and adversely affect emotional and social behavior (Janet 1889; Breuer et al. 1955). State-dependent memory has also been implicated in the persistence of drug addiction (Combe 1853), because addicts often encode information in drug-induced states that they can only recall it if they are back on drugs. Further mechanistic study of state-dependent learning will be broadly translatable to the development of treatments for psychopathologies that could be rooted in state-dependent learning, such as dissociative disorders (Maat et al. 2015) and addiction (Overton 1972; Ross and Schwartz 1974).

\section{Materials and Methods}

\section{Animals}

Of note, 8-9-wk-old male or female C57BL/6N mice were obtained from a commercial supplier (Harlan), individually housed on a 12-h light-dark cycle (lights on at 7 a.m.), and allowed ad libitum access to food and water. All animal procedures were approved by Northwestern University's Animal Care and Use Committee in compliance with U.S. National Institutes of Health standards.

\section{Cannulations and electrode surgeries}

Mice were anesthetized with $1.2 \%$ tribromoethanol (vol/vol). Using a stereotaxic apparatus, bilateral 26-gauge guided cannulas (Plastic One) were implanted, as described previously (Corcoran
A

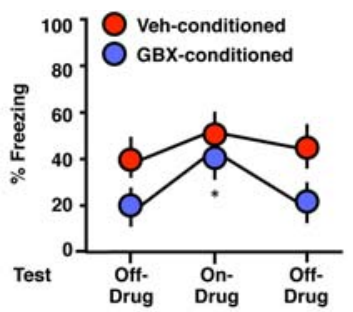

C

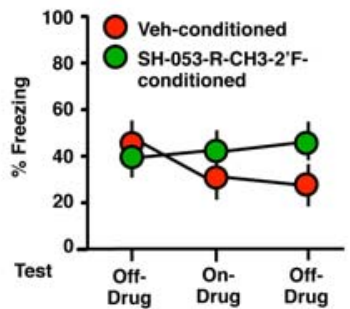

B

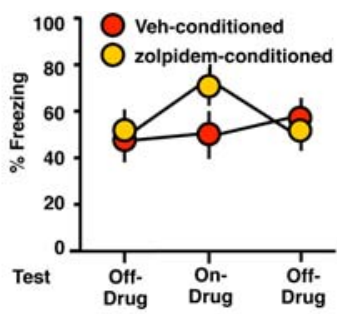

D

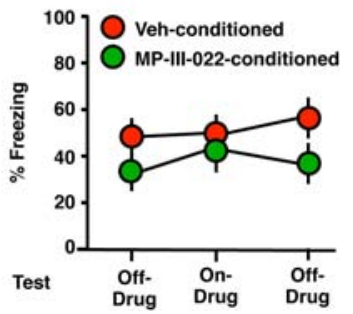

Figure 4. $\mathrm{GABA}_{\mathrm{A}} \mathrm{R} \alpha_{1-3,5}$-subunit preferential agonists do not induce state-dependent contextual fear conditioning. (A) Freezing behavior of GBX-conditioned mice was dependent upon testing conditions. $(B)$ The $\mathrm{GABA}_{A} \mathrm{R} \alpha_{1-3}$-subunit preferential agonist zolpidem did not affect freezing behavior. (C) $\mathrm{GABA}_{\mathrm{A}} \mathrm{R} \alpha_{5}$-subunit preferential agonist SH-053-R-CH3-2' $\mathrm{F}$ and $(D)$ MP-III-022 were also ineffective. $\left(^{*}\right) P<0.05$ versus Off-Drug test. Error bars represent standard error of the mean. 


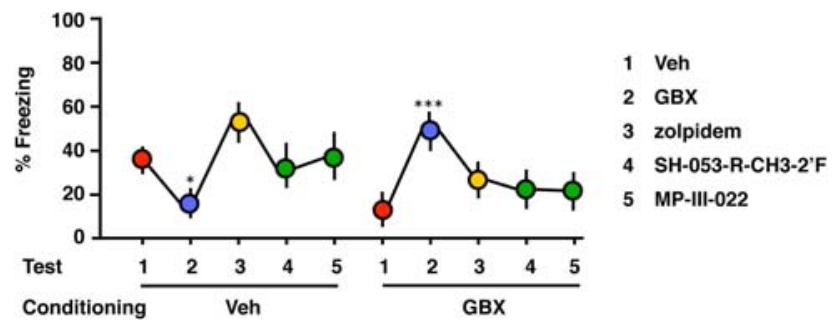

Figure 5. $\mathrm{GABA}_{\mathrm{A}} \mathrm{R} \alpha_{1-3,5}$-subunit preferential agonists do not recover memories formed under $G B X$. Veh-conditioned mice froze significantly less when tested on GBX. GBX-conditioned mice froze significantly more when tested again on GBX. $\left({ }^{*}\right) P<0.05,\left({ }^{* * *}\right) P<0.001$ versus Veh test. Error bars represent standard error of the mean.

et al. 2011), targeting the dorsal hippocampus (DH) (1.7 $\mathrm{mm}$ posterior, $\pm 1.0 \mathrm{~mm}$ lateral, and $2.0 \mathrm{~mm}$ ventral to bregma, according to the mouse brain atlas (Paxinos and Franklin 2004)). For electrode surgery, mice were implanted with insulated silver wires $(100 \mu \mathrm{m}$ diameter) aimed at RSC ( $1.8 \mathrm{~mm}$ posterior, $0.4 \mathrm{~mm}$ lateral, 0.75 $\mathrm{mm}$ ventral to bregma), DH (1.5 $\mathrm{mm}$ posterior, $1.0 \mathrm{~mm}$ lateral, $1.75 \mathrm{~mm}$ ventral $)$, and ACC $(1.3 \mathrm{~mm}$ anterior, $0.4 \mathrm{~mm}$ lateral, $1.75 \mathrm{~mm}$ ventral). All electrodes were placed in the left hemisphere. A gold screw lowered into the skull near the right parietal/occipital bone suture served as a reference and ground electrode. Two stainless steel jeweler's screws were inserted in the skull to anchor the headcap. All wires were soldered to a 6-pin connector to which the recording devices were later attached, and the assembly was fixed to the skull with acrylic. Mice were allowed at least $72 \mathrm{~h}$ to recover from surgery prior to behavioral procedures.

\section{Pharmacological treatments}

Drugs were injected i.h. at a volume of $0.25 \mu \mathrm{L}$ per side at a rate of $0.5 \mu \mathrm{L} \mathrm{min}{ }^{-1}$ or i.p. at a volume of $200 \mu \mathrm{L} 20-30$ min prior to fear conditioning or retrieval test. $\alpha_{4} \delta$ - and/or $\alpha_{6} \delta$-subunit-containing $\mathrm{GABA}_{\mathrm{A}} \mathrm{R}$ were activated by gaboxadol hydrochloride $(0.5 \mu \mathrm{g}$ per $\mathrm{DH}$, dissolved in artificial cerebrospinal fluid; Sigma-Aldrich) also known as 4,5,6,7-tetrahydroisoxazolo(5,4-c)pyridin-3-ol (THIP); $\alpha_{1-3}$-subunit-containing $\mathrm{GABA}_{\mathrm{A}} \mathrm{R}$ were activated by zolpidem (25 $\mu \mathrm{g}$ per DH, 100\% dimethyl sulfoxide (DMSO); Sigma-Aldrich); and $\alpha_{5}$-subunit-containing $\mathrm{GABA}_{\mathrm{A}} \mathrm{R}$ were activated by SH-053-RCH3-2'F (20 $\mu \mathrm{g}$ per DH, dissolved in 90\% DMSO; synthesized at University of Wisconsin-Milwaukee) or MP-III-022 (12.5 $\mu \mathrm{g}$ per DH; dissolved in 60\% DMSO; synthesized at University of Wisconsin-Milwaukee).

\section{LFP recordings}

On subsequent days following contextual fear conditioning, mice were tested for memory retrieval after i.p. injection of Veh $(0.9 \%$ saline; $0.2 \mathrm{~mL}$ and GBX (4 mg/kg in $0.2 \mathrm{~mL} 0.9 \%$ saline). LFP recordings began as soon as mice were connected to wireless four-channel NeuroLogger recording devices (TSE Systems), and continued until the end of each test session (up to $55 \mathrm{~min}$ total). Continuous recordings were made with a sampling rate of $500 \mathrm{~Hz}$. Preamplification, analog-to-digital conversion (unity gain buffer, AC input range $\pm 750 \mu \mathrm{V}, 1000 \times$ gain, ADC resolution 8bits), and data storage all occurred on the NeuroLogger. After each session, the NeuroLogger was removed and data were downloaded to a computer for later analysis.

For each of the test days, recordings were converted to a Matlab-compatible format for analysis of the $3 \mathrm{~min}$ mice were in their home cages just prior to drug injection, a $3 \mathrm{~min}$ period in the home cage beginning 30 min post-injection and ending immediately before mice were placed in the conditioning chambers, and the 3-min test sessions. Spectral analyses were performed using open-source Chronux (http://Chronux.org) algorithms as described previously (Kay and Freeman 1998; Rojas-Líbano et al. 2014). Power and coherence spectra were computed for the $\delta(1-$
$4 \mathrm{~Hz}), \theta(4-12 \mathrm{~Hz})$, and $\gamma(30-80 \mathrm{~Hz})$ frequency bands across each 3 min recording session using 35 half-overlapping 10 -sec windows with four tapers (resulting in a frequency resolution of $1.4 \mathrm{~Hz}$ ). Coherence was then transformed to $z$-coherence using the inverse hyperbolic tangent transform (Kay and Freeman 1998). There was no filtering. The peak frequency within each band was taken as the center frequency, and coherence at this peak was used as the dependent measure. Coherence, by definition, is normalized by power, allowing for direct comparison across subjects. Peak coherence and average power were calculated for each mouse in each session and used for statistical analysis.

\section{Fear conditioning}

Contextual fear conditioning was performed in an automated system (TSE Systems) as previously described (Corcoran et al. 2011). Briefly, mice were exposed for $3 \mathrm{~min}$ to context, followed by a footshock (3 sec, $0.8 \mathrm{~mA}$, constant current). In state-dependent contextual fear subunit specificity experiments, mice were exposed for $3 \mathrm{~min}$ to context, followed by a footshock $(2 \mathrm{sec}, 0.7 \mathrm{~mA}$, constant current). Twenty-four hours later, mice were tested for memory retrieval. Testing consisted of $3 \mathrm{~min}$ in the conditioning context, during which freezing was measured every 10 sec. Freezing was expressed as a percentage of the total number of observations during which the mice were motionless.

\section{Analysis}

Changes in power and peak coherence across recording sessions were determined separately for Veh and GBX using repeatedmeasures ANOVA. Following each significant F ratio, Tukey's HSD tests were used to determine the significance of two comparisons: (1) preinjection vs. post-injection in the home cage, and (2) post-injection in the home cage versus post-injection during the retrieval test. Changes in freezing were determined using two-way repeated-measures ANOVA. Following each significant $F$ ratio, Tukey's HSD tests were used to determine the significance of comparisons between two time points and Bonferroni tests were used to determine the significance of comparisons between three or more time points. Verification of electrode or cannula placements was made from coronal sections through DH, RSC, or ACC. Statistical analyses were performed using GraphPad Prism or StatView software.

\section{Acknowledgments}

This work was supported by NIMH grant MH078064 to J.R., the NIH grants MH096463 and NS076517 to J.M.C., the NIH Neurobiology of Information Storage training grant MH067564 to M.A.A.M., and the NUCATS grant UL1TR001422 and a Davee award to K.A.C. Additionally, we thank Anita Guedea for assistance with the behavioral experiments and the personnel at the University of Wisconsin-Milwaukee's Shimadzu Laboratory for Advanced and Applied Analytical Chemistry and the Milwaukee Institute for Drug Discovery who assisted with the synthesis of MP-III-022 and SH-053-R-CH3-2'F.

\section{References}

Barnhart SS, Abbott DW. 1967. Dissociation of learning and meprobamate. Psychol Rep 20: 520-522.

Belelli D, Harrison NL, Maguire J, Macdonald RL, Walker MC, Cope DV. 2009. Extrasynaptic GABAA receptors: form, pharmacology, and function. J Neurosci 29: 12757-12763.

Binder S, Rawohl J, Born J, Marshall L. 2014. Transcranial slow oscillation stimulation during NREM sleep enhances acquisition of the radial maze task and modulates cortical network activity in rats. Front Behav Neurosci 7: 220.

Blanchard RJ, Blanchard DC. 1969. Crouching as an index of fear. J Comp Physiol Psychol 67: 370-375.

Bódizs R, Kántor S, Szabó G, Szûcs A, Eröss L, Halász P. 2001. Rhythmic hippocampal slow oscillation characterizes REM sleep in humans. Hippocampus 11: 747-753. 
Braun BG. 1984. Towards a theory of multiple personality and other dissociative phenomena. Psychiatr Clin North Am 7: 171-193.

Breuer J, Freud S, Strachey J. 1955. Studies on hysteria. Basic Books, New York.

Brown N, Kerby J, Bonnert T, Whiting P, Wafford K. 2002. Pharmacological characterization of a novel cell line expressing human $\alpha 4 \beta 3 \delta$ GABAA receptors. Br J Pharmacol 136: 965-974.

Bruins Slot LA, Colpaert FC. 1999. Opiate states of memory: receptor mechanisms. J Neurosci 19: 10520-10529.

Bustamante JA, Jordán A, Vila M, González A, Insua A. 1970. State dependent learning in humans. Physiol Behav 5: 793-796.

Chandra D, Jia F, Liang J, Peng Z, Suryanarayanan A, Werner DF, Spigelman I, Houser CR, Olsen RW, Harrison NL, et al. 2006. GABAA receptor $\alpha 4$ subunits mediate extrasynaptic inhibition in thalamus and dentate gyrus and the action of gaboxadol. Proc Natl Acad Sci 103: 15230-15235.

Combe G. 1853. A System of Phrenology, 2 vols. Maclachlan Stewart, Edinburgh.

Corcoran KA, Donnan MD, Tronson NC, Guzmán YF, Gao C, Jovasevic V, Guedea AL, Radulovic J. 2011. NMDA receptors in retrosplenial cortex are necessary for retrieval of recent and remote context fear memory. J Neurosci 31: 11655-11659.

Corcoran KA, Frick BJ, Radulovic J, Kay LM. 2016. Analysis of coherent activity between retrosplenial cortex, hippocampus, thalamus, and anterior cingulate cortex during retrieval of recent and remote context fear memory. Neurobiol Learn Mem 127: 93-101.

Crestani F, Martin JR, Möhler H, Rudolph U. 2000. Mechanism of action of the hypnotic zolpidem in vivo. Br J Pharmacol 131: 1251-1254.

Dang-Vu TT, Schabus M, Desseille M, Albouy G, Boly M, Darsaud A, Gais S, Rauchs G, Sterpenich V, Vandewalle G. 2008. Spontaneous neural activity during human slow wave sleep. Proc Natl Acad Sci 105: 15160-15165.

Davis M. 1979. Diazepam and flurazepam: effects on conditioned fear as measured with the potentiated startle paradigm. Psychopharmacology (Berl) 62: 1-7.

Dudai Y. 2004. The neurobiology of consolidations, or, how stable is the engram? Annu Rev Psychol 55: 51-86.

Duncan PM, Copeland M. 1975. Asymmetrical state dependency from temporary septal area dysfunction in rats. J Comp Physiol Psychol 89: $537-545$.

Ebert B, Thompson SA, Saounatsou K, McKernan R, Krogsgaard-Larsen P, Wafford KA. 1997. Differences in agonist/antagonist binding affinity and receptor transduction using recombinant human $\gamma$-aminobutyric acid type A receptors. Mol Pharmacol 52: 1150-1156.

Frankland PW, Ding HK, Takahashi E, Suzuki A, Kida S, Silva AJ. 2006. Stability of recent and remote contextual fear memory. Learn Mem 13: $451-457$

Girden E, Culler E. 1937. Conditioned responses in curarized striate muscle in dogs. J Comp Psychol 23: 261.

Goodwin DW, Powell B, Bremer D, Hoine H, Stern J. 1969. Alcohol and recall: state-dependent effects in man. Science 163: 1358-1360.

Goshen I, Brodsky M, Prakash R, Wallace J, Gradinaru V, Ramakrishnan C, Deisseroth K. 2011. Dynamics of retrieval strategies for remote memories. Cell 147: 678-689.

Gruene TM, Flick K, Stefano A, Shea SD, Shansky RM. 2015. Sexually divergent expression of active and passive conditioned fear responses in rats. Elife 4: e11352

Hinrichsen JJ, Katahn M, Levenson RW. 1974. Alcohol-induced state-dependent learning in non-alcoholics. Pharmacol Biochem Behav 2: 293-296.

Janet P. 1889. L'automatisme psychologique: essai de psychologie expérimentale sur les formes inférieures de l'activité humaine. impr. Ch. Hérissey.

Jensen HH, Hutchings B, Poulsen JC. 1989. Conditioned emotional responding under diazepam: a psychophysiological study of state dependent learning. Psychopharmacology (Berl) 98: 392-397.

Jessen SB, Brazhe A, Lind BL, Mathiesen C, Thomsen K, Jensen K, Lauritzen M. 2014. GABAA receptor-mediated bidirectional control of synaptic activity, intracellular $\mathrm{Ca} 2+$, cerebral blood flow, and oxygen consumption in mouse somatosensory cortex in vivo. Cereb Cortex 25: 2594-2609.

Jovasevic V, Corcoran KA, Leaderbrand K, Yamawaki N, Guedea AL, Chen HJ, Shepherd GM, Radulovic J. 2015. GABAergic mechanisms regulated by miR-33 encode state-dependent fear. Nat Neurosci 18: $1265-1271$.

Kay LM, Freeman WJ. 1998. Bidirectional processing in the olfactory-limbic axis during olfactory behavior. Behav Neurosci 112: 541-553.

Kim JJ, Fanselow MS. 1992. Modality-specific retrograde amnesia of fear. Science 256: 675-677.

Langer S, Faure-Halley C, Seeburg P, Graham D, Arbilla S. 1992. The selectivity of zolpidem and alpidem for the $\alpha 1$-subunit of the GABA A receptor. Eur Neuropsychopharmacol 2: 232-234.

Lashley KS. 1950. In search of the engram.
Lebron-Milad K, Abbs B, Milad MR, Linnman C, Rougemount-Bucking A, Zeidan MA, Holt DJ, Goldstein JM. 2012. Sex differences in the neurobiology of fear conditioning and extinction: a preliminary fMRI study of shared sex differences with stress-arousal circuitry. Biol Mood Anxiety Disord 2: 7.

Lee V, Maguire J. 2014. The impact of tonic GABAA receptor-mediated inhibition on neuronal excitability varies across brain region and cell type. Front Neural Circuits 8

Lesburguères E, Gobbo OL, Alaux-Cantin S, Hambucken A, Trifilieff P, Bontempi B. 2011. Early tagging of cortical networks is required for the formation of enduring associative memory. Science 331: 924-928.

Ley P, Jain VK, Swinson RP, Eaves D, Bradshaw PW, Kincey JA, Crowder R, Abbiss S. 1972. A state-dependent learning effect produced by amylobarbitone sodium. Br I Psychiatry 120: 511-515.

Maat A, van Montfort SJ, de Nijs J, Derks EM, Kahn RS, Linszen DH, van Os J, Wiersma D, Bruggeman R, Cahn W, et al. 2015. Emotion processing in schizophrenia is state and trait dependent. Schizophr Res 161: 392-398.

McClelland JL, McNaughton BL, O'Reilly RC. 1995. Why there are complementary learning systems in the hippocampus and neocortex: insights from the successes and failures of connectionist models of learning and memory. Psychol Rev 102: 419-457.

Meera P, Wallner M, Otis TS. 2011. Molecular basis for the high THIP/ gaboxadol sensitivity of extrasynaptic GABAA receptors. I Neurophysiol 106: 2057-2064.

Milenkovic I, Vasiljevic M, Maurer D, Höger H, Klausberger T, Sieghart W. 2013. The parvalbumin-positive interneurons in the mouse dentate gyrus express GABAA receptor subunits $\alpha 1, \beta 2$, and $\delta$ along their extrasynaptic cell membrane. Neuroscience 254: 80-96.

Nakagawa Y, Iwasaki T. 1995. Involvement of benzodiazepine/GABA-A receptor complex in ethanol-induced state-dependent learning in rats. Brain Res 686: 70-76.

Nakagawa Y, Iwasaki T, Ishima T, Kimura K. 1993. Interaction between benzodiazepine and GABA-A receptors in state-dependent learning. Life Sci 52: 1935-1945.

Nusser Z, Roberts JD, Baude A, Richards JG, Sieghart W, Somogyi P. 1995. Immunocytochemical localization of the $\alpha 1$ and $\beta 2 / 3$ subunits of the GABAA receptor in relation to specific GABAergic synapses in the dentate gyrus. Eur J Neurosci 7: 630-646.

Olsen RW, Sieghart W. 2008. International Union of Pharmacology. LXX. Subtypes of $\gamma$-aminobutyric acid(A) receptors: classification on the basis of subunit composition, pharmacology, and function. Update. Pharmacol Rev 60: 243-260.

Olsen RW, Sieghart W. 2009. GABA A receptors: subtypes provide diversity of function and pharmacology. Neuropharmacology 56: 141-148.

Overton DA. 1964. State-dependent or "dissociated" learning produced with pentobarbital. J Comp Physiol Psychol 57: 3-12.

Overton DA. 1972. State-dependent learning produced by alcohol and its relevance to alcoholism. In The biology of alcoholism, Volume 2: physiology and behavior (ed. Kissin B, Begleiter H). Springer, Berlin Heidelberg New York.

Overton DA. 1991. Historical context of state dependent learning and discriminative drug effects. Behav Pharmacol 2: 253-264.

Patel JB, Ciofalo VB, Iorio LC. 1979. Benzodiazepine blockade of passive-avoidance task in mice: a state-dependent phenomenon. Psychopharmacology (Berl) 61: 25-28.

Paxinos G, Franklin KB. 2004. The mouse brain in stereotaxic coordinates. Gulf Professional Publishing, Houston.

Pritchett DB, Seeburg PH. 1990. $\gamma$-Àminobutyric acidA receptor $\alpha 5$-subunit creates novel type II benzodiazepine receptor pharmacology. I Neurochem 54: 1802-1804.

Rojas-Libano D, Frederick DE, Egana JI, Kay LM. 2014. The olfactory bulb theta rhythm follows all frequencies of diaphragmatic respiration in the freely behaving rat. Front Behav Neurosci 8: 214 .

Romieu P, Lucas M, Maurice T. 2006. Sigma1 receptor ligands and related neuroactive steroids interfere with the cocaine-induced state of memory. Neuropsychopharmacology 31: 1431-1443.

Ross SM, Schwartz CW. 1974. State-dependent learning and its implications for treatment of drug-abusers. Psychiatr Q 48: 368-373.

Rudolph U, Crestani F, Benke D, Brünig I, Benson JA, Fritschy JM, Martin JR, Bluethmann H, Möhler H. 1999. Benzodiazepine actions mediated by specific $\gamma$-aminobutyric acid(A) receptor subtypes. Nature 401: 796-800

Sanday L, Zanin KA, Patti CL, Fernandes-Santos L, Oliveira LC, Longo BM, Andersen ML, Tufik S, Frussa-Filho R. 2013. Role of state-dependent learning in the cognitive effects of caffeine in mice. Int J Neuropsychopharmacol 16: 1547-1557.

SavićMM, Clayton T, Furtmüller R, Gavrilović I, SamardzićJ, SavićS, Huck S, Sieghart W, Cook JM. 2008. PWZ-029, a compound with moderate inverse agonist functional selectivity at GABA(A) receptors containing $\alpha 5$ subunits, improves passive, but not active, avoidance learning in rats. Brain Res 1208: 150-159.

Sieghart W, Sperk G. 2002. Subunit composition, distribution and function of GABA(A) receptor subtypes. Curr Top Med Chem 2: 795-816. 
Spiegel D, Loewenstein RJ, Lewis-Fernández R, Sar V, Simeon D, Vermetten E, Cardeña E, Brown RJ, Dell PF. 2011. Dissociative disorders in DSM-5. Depress Anxiety 28: 824-852.

Squire LR, Alvarez P. 1995. Retrograde amnesia and memory consolidation: a neurobiological perspective. Curr Opin Neurobiol 5: 169-177.

Squire LR, Kandel ER. 2000. Memory: from mind to molecules. Macmillan, New York.

Stamenić TT, Poe MM, Rehman S, Santrač A, Divović B, Scholze P, Ernst M, Cook JM, Savić MM. 2016. Ester to amide substitution improves selectivity, efficacy and kinetic behavior of a benzodiazepine positive modulator of GABAA receptors containing the $\alpha 5$ subunit. Eur J Pharmacol 791: 433-443.

Sun C, Sieghart W, Kapur J. 2004. Distribution of $\alpha 1, \alpha 4, \gamma 2$, and $\delta$ subunits of GABAA receptors in hippocampal granule cells. Brain Res 1029: 207-216.

Vyazovskiy VV, Kopp C, Bösch G, Tobler I. 2005. The GABAA receptor agonist THIP alters the EEG in waking and sleep of mice. Neuropharm 48: 617-626.
Weingartner H, Adefris W, Eich JE, Murphy DL. 1976. Encoding-imagery specificity in alcohol state-dependent learning. J Exp Psychol Hum Learn 2: $83-87$.

Westerberg CE, Florczak SM, Weintrab S, Mesulam M, Marshall L, Zee PC, Paller KA. 2015. Memory improvements via slow-oscillatory stimulation during sleep in older adults Neurobiol Aging 36: 2577-2586.

Whiting PJ. 2003. GABA-A receptor subtypes in the brain: a paradigm for CNS drug discovery? Drug Discov Today 8: 445-450.

Wiltgen BJ, Tanaka KZ. 2013. Systems consolidation and the content of memory. Neurobiol Learn Mem 106: 365-371.

Zarrindast MR, Noorbakhshnia M, Motamedi F, Haeri-Rohani A, Rezayof A. 2006. Effect of the GABAergic system on memory formation and state-dependent learning induced by morphine in rats. Pharmacology 76: $93-100$.

Received March 10, 2017; accepted in revised form June 7, 2017. 


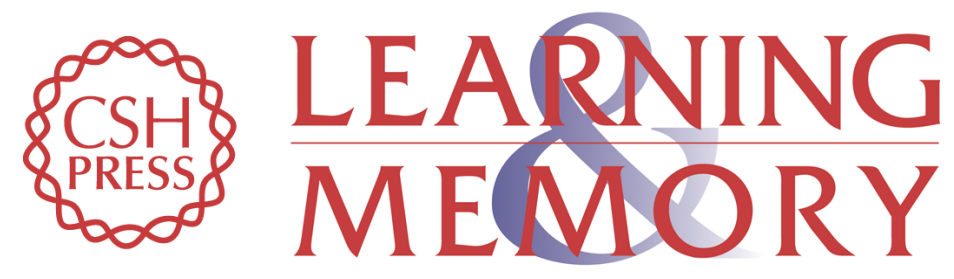

\section{Neurobiological correlates of state-dependent context fear}

Mariah A.A. Meyer, Kevin A. Corcoran, Helen J. Chen, et al.

Learn. Mem. 2017, 24:

Access the most recent version at doi:10.1101//m.045542.117

References This article cites 63 articles, 12 of which can be accessed free at: http://learnmem.cshlp.org/content/24/9/385.full.html\#ref-list-1

Creative This article is distributed exclusively by Cold Spring Harbor Laboratory Press for the Commons first 12 months after the full-issue publication date (see

License http://learnmem.cshlp.org/site/misc/terms.xhtml). After 12 months, it is available under a Creative Commons License (Attribution-NonCommercial 4.0 International), as described at http://creativecommons.org/licenses/by-nc/4.0/.

Email Alerting Receive free email alerts when new articles cite this article - sign up in the box at the Service top right corner of the article or click here. 